\title{
EXTENDING THE JUDICIAL CHECKLIST IN SCOTTISH FAMILY COURT \\ CASES: AN EXERCISE OF CAUTION OR A MISSED OPPORTUNITY?
}

\author{
Lesley-Anne Barnes Macfarlane *
}

In its General Comment no. 14 on Article 3 ('best interests') ${ }^{1}$ of the United Nations Convention on the Rights of the Child, ${ }^{2}$ the Committee on the Rights of the Child ('the Committee') described the creation of a comprehensive list of elements - i.e. a checklist - as 'useful' for providing 'concrete guidance, yet flexibility' in making decisions about children's best interests. ${ }^{3}$ The Committee also envisaged that the child's right to express a view (Article $12, \mathrm{UNCRC}^{4}$ ) would feature prominently in any such list. Other elements, or factors, specified by the Committee included, e.g., preservation of the child's identity and family relations, safety, health and education, all of which link directly to relevant rights set out in the UNCRC itself. $^{5}$

\section{A. SCOTLAND, AND ITS LIMITED FAMILY COURT CASE CHECKLIST}

The Children (Scotland) Act 1995 ('the 1995 Act') ${ }^{6}$ is the primary statute governing how private disputes between family members about a child's care and upbringing are resolved. These proceedings are referred to as 'family court cases' by the Scottish Government

\footnotetext{
* Lecturer in Law, Edinburgh Napier University.

${ }^{1}$ UN Committee on the Rights of the Child, 2013, General Comment No. 14 (2013) on the right of the child to have his or her best interests taken as a primary consideration (art. 3, para. 1), Part V. Hereinafter referred to as 'General Comment no. 14' or 'General Comment on Article 3': available from: https://www2.ohchr.org/English/bodies/crc/docs/GC/CRC C GC 14 ENG.pdf

${ }^{2}$ United Nations Convention on the Rights of the Child, 1577 UNTS 3, 20 Nov 1989. Hereinafter referred to as 'the UNCRC'.

${ }^{3}$ Para 50.

${ }^{4}$ Article 12(1) provides that 'States Parties shall assure to the child who is capable of forming his or her own views the right to express those views freely in all matters affecting the child, the views of the child being given due weight in accordance with the age and maturity of the child.'

${ }^{5}$ Paras 52 - 79. Specifically, the factors on the Committee's checklist in these paragraphs are: (a) the child's views; (b) the child's identity (including, e.g., religion, culture, gender, sexuality); (c) preservation of the family environment and maintaining relations; (d) care, protection and safety of the child; (e) situation of vulnerability (e.g., children with a disability, belonging to a minority group, refugees or asylum seekers); (f) the child's right to health: $(\mathrm{g})$ the child's right to education.

${ }^{6}$ Part 1 of the 1995 Act is concerned with disputes between private individuals. Part 2 of the Act, much of which has been repealed and re-enacted elsewhere, makes provision for the promotion of children's welfare by Local Authorities.
} 
in its policy publications. ${ }^{7}$ As with proceedings raised under the English Children Act 1989, the Scottish 1995 Act requires that the child's 'welfare' (a widely used UK synonym for 'best interests') is the court's 'paramount consideration' when determining such disputes. ${ }^{8}$ However, while English legislation sets out a comprehensive statutory list of factors that predates, but broadly mirrors, the checklist template provided by the Committee in its General Comment on Article 3, current Scottish legislation provides only a partial checklist to to aid judicial decision-making. ${ }^{9}$

The historic justification in Scotland for rejecting the inclusion of a comprehensive decisionmaking checklist in family legislation was expressed by the Scottish Law Commission almost three decades ago when, in its Report on Family Law, ${ }^{10}$ it produced a draft of what later became the 1995 Act. The Scottish Law Commission considered that a statutory list of factors would impose too 'mechanical' a decision-making process upon a Scottish court system practised in exercising wide discretion. ${ }^{11}$ This rationale pre-dates the recommendation of a checklist in General Comment no. 14 on Article 3 in 2013. ${ }^{12}$ In the most recent round of Scottish Family Law reform, the existing statutory checklist was considered by the Scottish Government and the Scottish Parliament. The resulting legislation, the Children (Scotland) Act 2020 Act ('the 2020 Act'), became law on 25 August 2020 and received Royal Assent on 1 October 2020.

The substantive provisions of the 2020 Act are not yet fully in force. The 2020 Act makes radical amendments to the legal principles and procedures governing family court cases including, most importantly, making greater provision for the involvement of children in decisions affecting them. ${ }^{13}$ By creating a pro-capacity presumption for the child, enabling

\footnotetext{
${ }^{7}$ See, e.g., Scottish Government Family Justice Modernisation Strategy, 2019, p 17, available at: https:/www.gov.scot/binaries/content/documents/govscot/publications/strategy-plan/2019/09/family-justicemodernisation-strategy/documents/family-justice-modernisation-strategy/family-justice-modernisationstrategy/govscot\%3Adocument/family-justice-modernisation-strategy.pdf.

${ }^{8}$ Children Act 1989, s 1(2); Children (Scotland) Act 1995, s 11(7)(a).

${ }^{9}$ For the English statutory checklist, see s 1(3)(a)-(g), and also s 1(2A) and 1(2B), inserted by the Children and Families Act 2014. The Scottish list of factors, or checklist, can be found in s 11 of the 1995 Act and is discussed in the main text below.

${ }^{10}$ Scottish Law Commission, Report on Family Law, No. 135, 1992. Edinburgh: HMSO.

${ }^{11}$ Para 5.22.

${ }^{12}$ See notes 1 and 5 above.

${ }^{13}$ For a detailed discussion of the Children's Right-based provisions of the 2020 Act in L-A Barnes Macfarlane, 2019. The Children (Scotland) Bill 2019. Balancing the Rights of Parents and Children, chapters 7A-C: https://www.parliament.scot/S5 JusticeCommittee/Inquiries/Balancing the Rights of Parents and Children Reportv2.pdf. See also F Morrison F., EKM Tisdall, J Warburton, A Reid \& F Jones, 2019. 'Children's
} 
views to be expressed the child's preferred manner and requiring the court to provide the child with feedback on its decision, ${ }^{14}$ the 2020 Act represents a significant step forward in terms of better aligning Scottish Law with the UNCRC. However, perhaps surprisingly, given Scotland's progression towards full incorporation of the UNCRC, the 2020 Act does not significantly extend the existing, and very limited, statutory checklist provided in the 1995 Act to guide Scotland's judiciary in determining family disputes.

The decision-making process currently set down in section 11 of the 1995 Act provides three overarching factors for court's consideration in deciding whether to grant orders. These are: (i) the paramountcy of child's welfare, as noted above; (ii) the no order principle; (iii) the obligation to provide children with an opportunity to express a view to which the court must have regard. ${ }^{15}$ Since 2006, following the passage of the Family Law (Scotland) Act of that year, additional requirements to which the court must also direct its mind were inserted into section 11 of the 1995 Act. These oblige the court first to 'have regard in particular to... the need to protect the child from... abuse or... the risk of any abuse', and secondly, to consider parental ability 'to co-operate with one another as respects matters affecting the child' before granting any orders. ${ }^{16}$ Thus, with the exceptions of giving the child an opportunity to express a view and protection from abuse, the existing Scottish checklist does not include the specific factors ${ }^{17}$ recommended by the Committee on the Rights of the Child.

The 2020 Act repeals all of the existing statutory factors, broadly re-enacting each of them elsewhere in Part 1 of the 1995 Act. These factors will now be divided between two new sections inserted by the 2020 Act into the 1995 Act. A new section 11ZA, entitled 'Paramountcy of child's welfare and the non-intervention presumption', contains two of the above factors and two new statutory factors, which are discussed below. The new section 11ZB ('Regard to be had to the child's views') is concerned only with the expression of views by children.

\footnotetext{
Participation In Family Actions - Probing Compliance With Children's Rights Research Report', Scottish Government.

${ }^{14}$ New S 11ZB; 11F of the 1995 Act, inserted by the 2020 Act, ss 1, 20 (provisions not yet in force).

15 Section 11(7)(a) \& (b).

${ }^{16}$ Section $11(7 \mathrm{~A})-7(\mathrm{E})$.

${ }^{17}$ See note 5 above.
} 


\section{B. OBSERVATIONS ON THE NEW SECTIONS 11ZA AND 11ZB}

Two observations might be made about these new sections. The first relates to the structure of 1995 Act as amended. The 2020 Act separates, for the first time since 1995, those provisions relating to the child's views (new section 11ZB) from those provisions relating to the other matters to which the court should have regard (new section 11ZA). Will this act of division prove significant?

Certainly, the Committee on the Rights of the Child placed the child's views at the beginning of the list of factors it considered should 'be taken into account [by courts] assessing and determining the child's best interests'. ${ }^{18}$ While the Committee stressed that the list itself was not intended to be exhaustive or hierarchical, their rationale for including the child's views within a list about determining best interests was that:

'Any decision that does not take into account the child's views... does not respect the possibility for the child... to influence the determination of their best interests.' 19

Accordingly, the Committee emphasised that the child's right to express a view is not only a free-standing human right in terms of Article 12, but also an integral step in any Article 3 process about determining the child's best interests, or welfare. The explanation provided by the Scottish Government for not including reference to the child's views within the updated statutory checklist in section 11ZA was that the court's duty to have regard to the child's views has been provided for elsewhere - in the new section $11 \mathrm{ZB} .{ }^{20}$ Yet the absence of any reference to the child's views in the new section 11ZA containing the other factors on the judicial checklist is conspicuous. This is not merely a question of style over substance: the duty to take the child's view should not be considered as an adjunct to the court's other decision-making steps. The new checklist does not, therefore, seem to be optimally balanced to achieve what the Committee on the Rights of the Child describes as 'the full and effective enjoyments of the rights recognized [sic] in the Convention'. ${ }^{21}$

\footnotetext{
${ }^{18}$ General Comment no. 14 on Article 3, para 52.

${ }^{19} \mathrm{Ibid}$, para 53.

${ }^{20}$ Scottish Government, Policy Memorandum accompanying the Children (Scotland) Bill, 2019, paras 142 148, available from: https://archive2021.parliament.scot/S5 Bills/Children\%20(Scotland)\%20Bill/SPBILL52PMS052019.pdf.

${ }^{21}$ General Comment no. 14 on Article 3, para 51
} 
The second observation on the revised list of factors for the Scottish judiciary concerns the two new factors created by the 2020 Act and which form part of the new section 11ZB(3)(f) of the 1995 Act. These are that the court must consider the impact that any order it may grant could have upon: (i) 'the involvement of the child's parents' in the child's upbringing and (ii) the child's 'important relationships with other people'. The new section 11ZB(3)(f) paraphrases one of the factors found on the list drafted by the Committee on the Rights of the Child in its General Comment on Article 3. ${ }^{22}$ The wording of this new section recognises that the child's important relationships may be with friends rather than family members.

However, the revised Scottish checklist does not include any of the other factors recommended by the Committee which create a duty upon the decision maker to consider the child's specific personal characteristics in making a best interests decision (e.g., the child's identity, educational needs, health etc.). Here, it appears that the Scottish Government erred on the side of caution when considering whether and how the existing statutory list of factors might be extended, taking the view that courts 'already take [the age, sex and background of the child concerned] into account in all cases. ${ }^{23}$ Thus, deciding which specific matters to take into account in reaching a decision about the child's best interests will, as before, remain a matter falling within the wide - some might argue arbitrary - discretion of Scotland's judiciary.

\section{STATUTORY CHECKLISTS - A SUBJECT FOR DISCUSSION AND DEBATE}

The content of statutory checklists used for reaching decisions about children's care and upbringing have presented much opportunity for discussion and debate over the years, and across a range of jurisdictions. ${ }^{24}$ In America, for example, almost all States require courts to consider the issue of domestic abuse in making decisions in family cases about the child's best

\footnotetext{
22 General Comment no. 14 on Article 3, paras 58-70.

${ }^{23}$ Scottish Government, Policy Memorandum accompanying the Children (Scotland) Bill, 2019, para 148.

${ }^{24}$ See, e.g., (USA) JB Kelly, The Best Interests of the Child: A Concept in Search of Meaning, 35 Fam. \& Council. Cts. Rev. 377, 384 (1997); (Australia) P Parkinson \& J Cashmore, 2019. Children's Participation in Decisions about Parenting Arrangements, in GD James Dwyer (Eds.), The Oxford Handbook of Children and the Law. Oxford: Oxford University Press; (England) J Harwood (2021) Presuming the status quo? The impact of the statutory presumption of parental involvement, Journal of Social Welfare and Family Law, 43:2, 119-142; (Scotland) EE Sutherland, 2018. 'The welfare test: determining the indeterminate', Edinburgh Law Review 22(1), 94
} 
interests, although there is greater variation among States in respect of other factors specified. ${ }^{25}$ The (now amended) Australian Family Law (Shared Parental Responsibility) Act 2006 provides a well-documented example of the detrimental effect that a checklist containing a presumption of shared parenting had upon the safety children in cases involving domestic abuse. That checklist generated a 'presumption of equal parental responsibility [being] wrongly taken to mean that there was also a presumption favouring children spending equal time with each parent', regardless of family circumstances. ${ }^{26}$

The Australian experience also raises another issue related to the balance of checklists, namely the weight to be afforded in practice to individual factors included in a statutory checklist. Typically, checklists leave courts free to apportion weight in the manner they consider appropriate. On the question of weight, the Committee on the Rights of the Child does not elevate one factor above the others, instead noting that different factors may be relevant in different circumstances and deferring to the decision-maker in the individual case, observing that:

'Determining what is in the best interests of the child should start with an assessment of the specific circumstances that make the child unique. This implies that some [factors] will be used and others will not, and also influences how they will be weighted against each other.' 27

Where Scotland is concerned, a longstanding criticism of the judicial checklist currently found in the 1995 Act is that it appears incomplete, with one commentator noting that 'having a partial checklist is worse than having none at all'. ${ }^{28}$ Such an incomplete checklist, arguably, does not fully support transparency and accountability in reaching decisions about the child's best

\footnotetext{
${ }^{25}$ LDH Elrod, 2019. Child Custody Practice and Procedure. Thomson Reuters: Thomson: US Government Works, at 4:2.

${ }^{26}$ R Chisholm, 2009. 'Family Courts Violence Review', Attorney General Department, Australia, p 8, available at:

https://www.ag.gov.au/sites/default/files/2020-03/Family\%20Courts\%20Violence $\% 20$ Review.pdf.

${ }^{27}$ General Comment no. 14 on Article 3, paras 49; 80-84.

${ }^{28}$ EE Sutherland, 2017. Family Law: Still Scope for Reform, Journal of the Law Society of Scotland. Available from:

https://www.lawscot.org.uk/members/journal/issues/vol-62-issue-07/family-law-still-scope-forreform/\#.XXdj4LpFyUk
} 
interests. In its Guidance on Article 3, the Committee on the Rights of the Child provided a clear children's rights-based template of specific factors relevant to determining best interests. That the amendments made by the 2020 Act do not extend the current Scottish checklist by importing the Committee's recommended factors can be viewed either as an exercise in caution or as a missed opportunity. It is suggested that this is likely to become a matter of debate as the provisions of the 2020 Act come fully into force.

As Scotland moves towards fully incorporating the United Nations Convention on the Rights of the Child, the 2020 Act represents an important step towards safeguarding and promoting children's rights within Family Law. However, the failure to complete the current partial statutory checklist will be viewed in a number of quarters as a missed opportunity. 